\title{
FREE ACCESS \\ Spatially explicit model of wintering common loons: conservation implications
}

\author{
Kristopher J. Winiarski ${ }^{1,2, *}$, David L. Miller ${ }^{1}$, Peter W. C. Paton ${ }^{1}$, Scott R. McWilliams ${ }^{1}$ \\ Department of Natural Resources Science, University of Rhode Island, 1 Greenhouse Road, Kingston, Rhode Island 02881, USA \\ ${ }^{2}$ Present address: Department of Environmental Conservation, University of Massachusetts, 160 Holdsworth Way, Amherst, \\ Massachusetts 01003, USA
}

\begin{abstract}
Common loons Gavia immer are a conservation concern in New England due to a variety of anthropogenic factors, yet little is known about biotic and abiotic environmental factors determining their wintering distribution and abundance in nearshore and offshore waters. The primary objective of this study was to develop a spatially explicit abundance model of wintering common loons in the maritime waters of southern New England (USA) that could inform decisions about offshore development. Aerial line-transect surveys were conducted throughout a $3800 \mathrm{~km}^{2}$ study area off the coast of Rhode Island during the winters of 2010-2011 and 2011-2012. A density surface model (DSM) approach was used to account for imperfect detection and incorporate spatially explicit environmental covariates. Common loon densities were greatest in waters $<35 \mathrm{~m}$ deep, with high chl a surface concentrations $\left(>2 \mathrm{mg} \mathrm{m}^{-3}\right)$. The DSM predicted $5047(95 \% \mathrm{CI}=$ 3993-6379) common loons in the study area during winter, which suggests this region provides key habitat for this species in eastern North America. This study highlights important areas for common loons in the region, suggests key biotic (primary productivity as measured by long-term chl a surface concentrations) and abiotic covariates (water depth) driving the spatial distribution and abundance of common loons in southern New England, and identifies sites that should be considered for protection from offshore development, including offshore wind facilities.
\end{abstract}

KEY WORDS: Aerial line-transect survey $\cdot$ Chlorophyll a . Density surface model $\cdot$ Distance sampling $\cdot$ Gavia immer $\cdot$ Spatially explicit abundance models

\section{INTRODUCTION}

Common loons Gavia immer are of conservation concern in the northeastern USA due to a variety of anthropogenic factors including human intrusion at breeding lakes (Titus \& Van Druff 1981, Jung 1991), commercial fishing (Forsell 1999), acid rain (Alvo et al. 1988), mercury exposure (Evers et al. 1998, Burgess \& Meyer 2008), lead poisoning (Sidor et al. 2003), and marine oil spills (Sperduto et al. 2003). Current population estimates are approximately 5500 common loons nesting in New England and New York (Evers 2007), with the species classified as a species of concern in Massachusetts, New York, and Connecticut, threatened in New Hampshire, and endangered in Vermont (Evers 2007, Kenow et al. 2009). Recent satellite telemetry research suggests that common loons breeding throughout the northeastern USA primarily winter in nearshore waters from Maine to New Jersey (Kenow et al. 2009), although little is known about the biotic and abiotic environmental factors that affect their distribution and abundance when using marine waters in this region during winter (Daub 1989, Ford \& Gieg 1995, Kenow et al. 2009). Available evidence suggests that wintering common loons primarily occur in shallow ( $<20 \mathrm{~m}$ deep), nearshore marine waters, although low densities occur out to $100 \mathrm{~km}$ offshore (Powers \& Cherry 1983, Haney 1990). The spatial distribution of loons during winter is thought to be driven by prey 
availability (Evers 2007), which appears to be influenced by water clarity (McIntyre 1978, Thompson \& Price 2006), water depth (Daub 1989, Kenow et al. 2009), and tidal regime (McIntyre 1978, Daub 1989).

Due to the likely development of large-scale offshore wind energy developments (OWEDs) in the waters of southern New England within the next decade, there is a pressing need to understand the environmental factors driving the distribution and abundance of common loons and other marine vertebrates in the region. Loons are especially sensitive to OWED, as well as to shipping and helicopter traffic (Petersen et al. 2006, Schwemmer et al. 2011, Furness et al. 2013, Langston 2013). Thus, gathering accurate information on the spatial patterns of common loons is essential for siting of OWEDs in maritime waters of the northeastern USA to minimize risk to extant common loon populations (Fox et al. 2006, Langston 2013).

Our primary objective was to develop a spatially explicit abundance model of wintering common loons in the maritime waters of southern New England. We used this model to identify sites that supported high densities of common loons and thus should be considered for protection from development of OWEDs. We built a density surface model (DSM; Hedley \& Buckland 2004) using data from aerial line transect surveys to provide a spatially explicit estimate of the density of common loons during winter off the coast of Rhode Island. DSMs consist of a spatial model of counts of animals, with the counts adjusted for imperfect observer detectability. We explored the relationships between common loon distribution and abundance and multiple spatially explicit environmental covariates including latitude, longitude, closest distance to coast, water depth, sediment median grain size, bottom roughness and multiple metrics of remotely sensed chlorophyll a $(\mathrm{chl}$ a). Several of these environmental covariates relate to the distribution and abundance of other species of marine birds (Louzao et al. 2009, Tremblay et al. 2009, Suryan et al. 2012, Watson et al. 2013), which allowed us to determine whether these covariates relate to spatial patterns of common loons using marine waters in the Northwest Atlantic.

\section{MATERIALS AND METHODS}

\section{Study area}

Surveys were conducted in the Rhode Island Ocean Special Area Management Plan (OSAMP) study area (http://seagrant.gso.uri.edu/oceansamp/), which encompassed approximately $3800 \mathrm{~km}^{2}$ in Rhode Island Sound, Block Island Sound, and portions of the Inner Continental Shelf, an area currently under consideration for multiple OWEDs (Fig. 1; Winiarski et al. 2011). Mean $( \pm$ SD) water depth in the study area was $34.9 \pm 9.9 \mathrm{~m}$, with approximately $8 \%$ of the area $<20 \mathrm{~m}$ deep and $86 \%$ between 20 and $50 \mathrm{~m}$ deep (Fig. 1d).

\section{Aerial-based line transect surveys}

Following protocols developed by Camphuysen et al. (2004), aerial line transects were conducted to survey common loons throughout this study area. Approximately 3 aerial surveys per month were conducted, from 1 December to 28 February in 2010-2011 and 2011-2012 for a total of 14 aerial surveys. Although our surveys were restricted to the daytime, Kenow et al. (2009) found that satellitetagged common loons had relatively small home ranges on their wintering grounds; thus we assumed their locations during daytime and nighttime were similar. All aerial surveys occurred around midday (usually between 10:00 and 15:00 h) on 24 transect lines, oriented perpendicular to the coast and spaced $3 \mathrm{~km}$ apart, with a mean $( \pm \mathrm{SD})$ transect length of 46.3 $\pm 12.3 \mathrm{~km}$ (min.-max. = 7.8-58.0 km) (Fig. 1f). Locations of the 24 transects were determined using the survey design tool in Distance 6.1 which randomly placed a grid of transect lines over the study area (Thomas et al. 2010). Each transect line was surveyed once per month, with 8 transect lines (every third transect) sampled during each aerial survey. We conducted all aerial surveys from a twin-engine Cessna Skymaster aircraft that flew at an altitude of $76 \mathrm{~m}$ above mean sea level at a constant speed of $160 \mathrm{~km}$ $\mathrm{h}^{-1}$, when wind speed was less than $35 \mathrm{~km} \mathrm{~h}^{-1}$ or waves were $<1.2 \mathrm{~m}$ tall. Two observers on each survey flight were located behind the pilot and co-pilot seats (one on each side of the plane), and each observer recorded all birds observed on their side of the plane within 3 distance bins out to $1000 \mathrm{~m}$ (Bin A = 44-163 $\mathrm{m}$ [note: we could not see underneath the plane from 0 to $44 \mathrm{~m}]$, Bin $\mathrm{B}=164-432 \mathrm{~m}$, Bin $\mathrm{C}=$ 433-1000 m; Camphuysen et al. 2004). A clinometer was used to mark set angles with black tape on the aircraft's wing struts delineating the 3 distance bins. Observers used their unaided eyes to detect individuals or flocks, identifying species when possible or to an avian guild (e.g. unidentified loon species) when necessary. Loons were recorded as either on the 

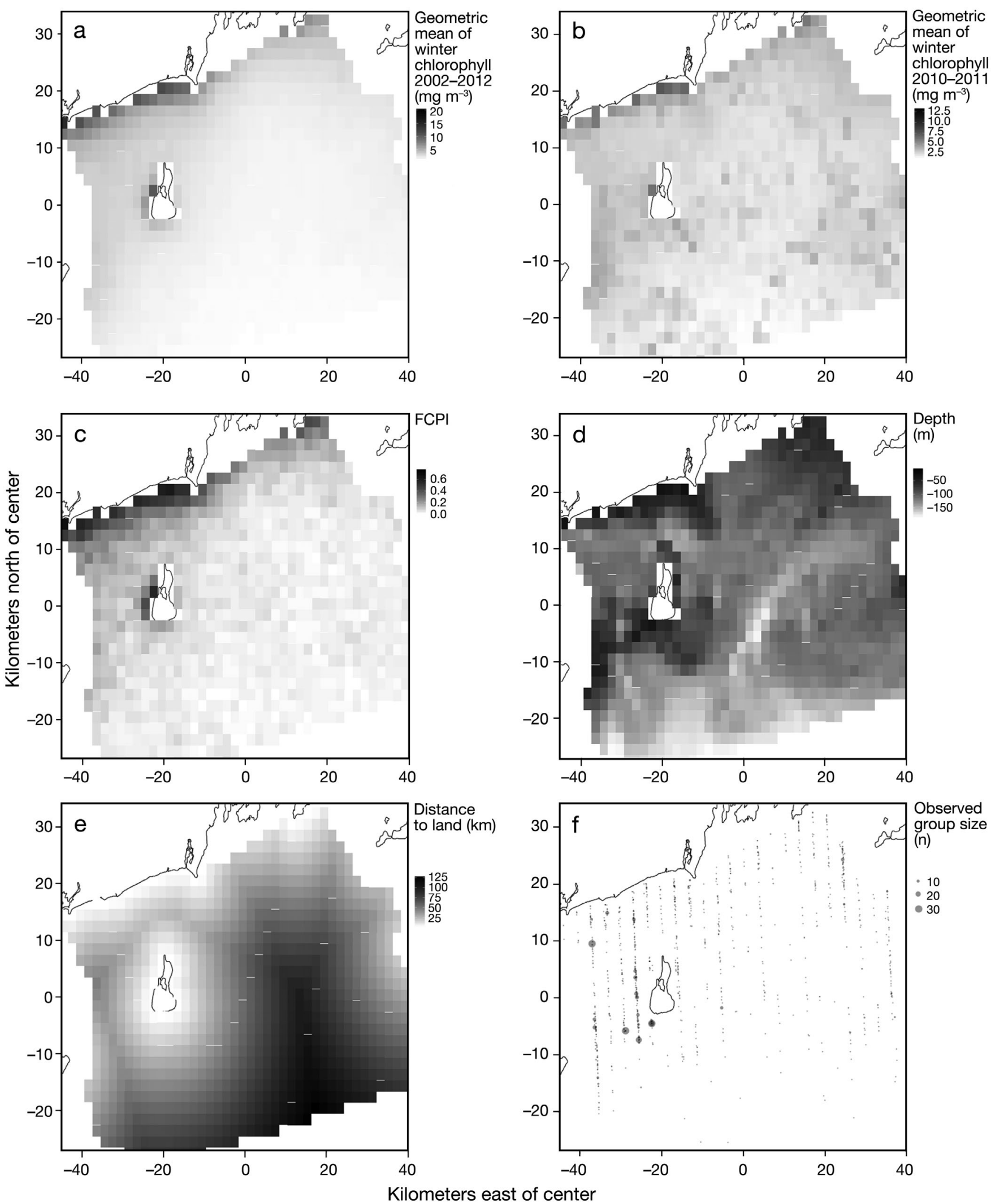

Fig. 1. Spatial distribution of environmental covariates included in overall model selection: (a) geometric mean of chlorophyll a (chl a) surface concentration from 2002-2012 (gchl_long), (b) geometric mean of chl a surface concentration for winters 2010-2011 and 2011-2012 (gchl_winter), (c) frequency of chl a peaks index (FCPI) from 2002-2012 (fcpi; Suryan et al. 2012), (d) water depth (depthm), (e) distance to coast (distancelandkm). (f) Raw observations of common loon Gavia immer from aerial line transect surveys. Black line: coast (Block Island, RI, located near the middle of the study area, mainland RI to the north and Long Island, NY, to the west) 
water or in flight. Observers recorded common loon sightings to the nearest second on a digital voice recorder. Each observer had a digital stopwatch that was synchronized with a global positioning system (GPS; Garmin model No. 496) that recorded the aircraft's position every $2 \mathrm{~s}$. Due to the orientation of the transect lines and the sun, glare affected observer's detection rates of loons on sunny days when conducting surveys from north to south along transect lines; if glare compromised detection rates on one side of the plane, then that surveyor ceased collecting data.

\section{Density surface modeling}

We used data from aerial line-transect surveys to build a density surface model that estimated the distribution and abundance of common loons during winter in our study area. Development of the DSM proceeded in 2 steps: (1) abundances were estimated from line transect data using distance sampling methods (Buckland et al. 2001), then (2) a generalized additive model (GAM; e.g. Wood 2006) was fitted to those abundances with explanatory variables provided by spatially referenced environmental covariates. These abundances were calculated per segment by subdividing transects into contiguous, $2270 \mathrm{~m}$ long segments. Length of segments was determined by the spatial scale of the modeled environmental covariates. Since $<5 \%$ of detections were of loons in flight that were assumed to not be actively foraging, only detections of common loons on the water were analyzed so that the spatial model indicated where common loons were most likely foraging.

Fitting a detection function. To estimate loon abundance for each segment, a detection function was fitted to all common loon detections using standard distance sampling methodology for binned data (Buckland et al. 2001, 2004). In contrast to striptransect surveys where detection probability is assumed to be 1 , detection function models assume all loons were detected at zero distance from the transect line, with detectability decreasing with increasing distance from observer. Both half-normal and hazard-rate detection functions were fitted to the full line-transect data that combined all segments. Group size and observer identity were available as covariates to be used in the detection function. When covariates were not included in the detection function, cosine adjustment terms were added to the models, as well as Hermite polynomials (for the halfnormal detection function) and simple polynomials (for the hazard-rate detection function). Akaike's Information Criteria (AIC) was used to select among candidate detection functions. All analyses were performed using the 'Distance' package version 0.7.1 (Miller 2012) for R version 3.0.1 (R Development Core Team 2012).

The estimated number of individuals (n̂) in segment $j$ was given by

$$
\hat{\mathrm{n}}_{j}=\sum_{r_{j=1}}^{R_{j}} \frac{S_{r_{j}}}{\hat{p}}
$$

if there were $R_{j}$ observations in segment $j$ and the flock size of flock $r_{j}$ was $S_{r j}$. The probability of detection was denoted $\hat{p}$ and was calculated by integrating the detection function over the observation window (44 to $1000 \mathrm{~m}$ ) and dividing through by this interval, the truncation distance $(956 \mathrm{~m})$; see Buckland et al. (2001) for further details. Truncation was chosen so that all observations could be included in the analysis.

Availability bias. Diving birds, such as common loons, are not always available at the surface of the water to be counted. In order to correct for individuals that were unavailable for detection when diving underwater, counts of common loons were divided per segment by the proportion of time that common loons were available, thus appropriately inflating the estimated counts. Using data from Ford \& Gieg (1995), who recorded the percentage of time common loons spent underwater when wintering off the coast of Rhode Island, common loons in waters $>5.5 \mathrm{~m}$ were assumed to be available for detection on average $70 \%$ of the time.

Environmental covariates. Due to an absence of spatial data of known common loon prey, including small demersal fish, flounder, crabs and lobsters (Creaser et al. 1993, Evers 2007), we used 6 abiotic (latitude, longitude, closest distance to coast, water depth, sediment median grain size, bottom roughness) and 3 biotic factors (derived metrics of remotely sensed chl a) in the model as proxies for loon prey and prey abundance.

Abiotic variables: Northing $(y)$ and easting $(x)$ were calculated as distances $(\mathrm{km})$ from the center of the region of interest $\left(41.17^{\circ} \mathrm{N}, 71.34^{\circ} \mathrm{W}\right)$ using the spherical law of cosines, which assumes the Earth is a sphere with radius $6371 \mathrm{~km}$ (Fig. 1). Sediment median grain size (phimedian; Reid et al. 2005) was obtained from the National Oceanic and Atmospheric Administration (NOAA) Geophysical Data Center (www.ngdc.noaa.gov). Bottom roughness (roughness; Lafrance et al. 2010) was calculated as the standard deviation (SD) of bottom slope within a search radius of $1000 \mathrm{~m}$ and a moving window algo- 
rithm using the slope tool in ArcGIS 10.0. Water depth $\left(\mathrm{m}_{\text {; depthm }}\right)$ was obtained from the NOAA Coastal Relief Model (www.ngdc.noaa.gov/mgg/ coastal/crm.html).

Biotic variables: Assuming high densities of common loon prey would be found in areas of high primary productivity, we included 3 different measures of chl a surface concentration $\left(\mathrm{mg} \mathrm{m}^{-3}\right)$, which were calculated from chl a concentration obtained with the Aqua MODIS satellite (NOAA Environmental Research Division's Data Access Program; http://coastwatch.pfeg.noaa.gov/erddap/index.html): geometric mean of chl a surface concentration for winters 2010-2011 and 2011-2012 (gchl_winter); 10 yr geometric mean (2002-2012) of chl a surface concentration (gchl_long, based on the monthly average); and the frequency of chl a peaks index (FCPI) (fcpi; Suryan et al. 2012) based on the 10-yr (2002-2012) geometric mean (Fig. 1a-c). The FCPI (Suryan et al. 2012) provided a measure of long-term deviation from the temporal trend in the chl a surface concentration level at each measurement location. The FCPI was calculated in 3 steps, following Suryan et al. (2012): (1) $z$-score-standardising the monthly logarithm of chl a surface concentration, (2) fitting a model of monthly trends over the whole region (including yearly and monthly cyclic trends), and (3) calculating the proportion of time that the value of chl a surface concentration at a given location had a positive anomaly $>1 \mathrm{SD}$ from the model (for details, see the Supplement at www.int-res.com/articles/ suppl/m492p273_supp.pdf). Using these 3 measures of chl a surface concentration, we investigated which metric would be more useful in predicting the distribution and abundance of common loons in our study area. This allowed us to test a hypothesis proposed by Suryan et al. (2012) that the FCPI was not as useful as mean-based chl a surface concentration for predicting the distribution and abundance of a coastal marine bird species.

Smooth terms. The basis functions used for the smooth terms in the model were thin plate regression splines (Wood 2003). The maximum basis size controlled the maximum complexity of the smooth terms; since the smooth terms were penalized, only the maximum basis size needed to be set and the penalty reduced the complexity of the smooth terms to an appropriate level whilst maintaining a good fit (Wood 2006, Section 4.1.7). The maximum basis size was set to 10 for univariate smooth terms and 18 for bivariate smooth terms.

Fitting. Models were fitted using the 'dsm' package for R (Miller 2013). Smoothness selection for the smooth terms in the model was performed via restricted maximum likelihood (REML; Wood 2011). REML was preferable to generalized cross validation/ unbiased risk estimator-based estimation because REML tends to have a more pronounced optima (Wood 2011). When models contain highly correlated covariates, REML was more likely to find an optimal degree of smoothing. For example, water depth was effectively a smooth function of location and could therefore cause issues during model fitting.

Model selection. The estimated number of common loons in segment $j$ was modeled as a sum of smooth functions of the $k$ explanatory variables $\left(z_{j k}\right)$ using a GAM with the general formulation:

$$
E\left[\hat{\mathrm{n}}_{j}\right]=\exp \left[\log \left(a_{j}\right)+\beta+\sum_{k=1}^{K} f_{k}\left(z_{j k}\right)\right]
$$

where $\hat{\mathrm{n}}_{j} \sim \operatorname{NegativeBinomial}(\theta), E$ indicates expectation, $a_{j}$ is an offset (the area of the segment, taking into account 1 - or 2 -sided transects), $\beta$ is an intercept and $f_{k}$ are smooths of the $K$ explanatory variables. The $\theta$ parameter of the negative binomial distribution was estimated during model fitting (see the Supplement).

The 'base' model included the $3 \mathrm{chl}$ a surface concentration metrics and all the abiotic variables as univariate smooths as well as a bivariate smooth of spatial location. Covariate selection then proceeded via 2 mechanisms: (1) an extra penalty for each smooth which allowed smooth terms to be completely removed from the model during fitting (Wood 2006, Section 4.1.6; Wood 2011), and (2) approximate pvalues to select which smooth terms were significant. Once models had been fitted, the residuals were checked for spatial autocorrelation by inspecting the correlogram, which showed the behavior of the correlation between segments at a series of lags.

Abundance estimation. Once a model was selected, abundance was predicted over the entire study area using a spatially referenced grid of $920 \times 2 \mathrm{~km}^{2}$ predictive cells. Summing over the predicted values for all grid cells resulted in an estimate of abundance over the whole study area.

Variance estimation. The variance of abundance in each grid cell and the overall abundance estimate were obtained by the variance propagation method of Williams et al. (2011). This method incorporates uncertainty from the estimation of the detection function parameters as well as from the GAM by fitting a second model (used only for variance calculations). The coefficient of variation for each prediction grid cell was calculated and plotted over the study area to illustrate the uncertainty in our DSM. 


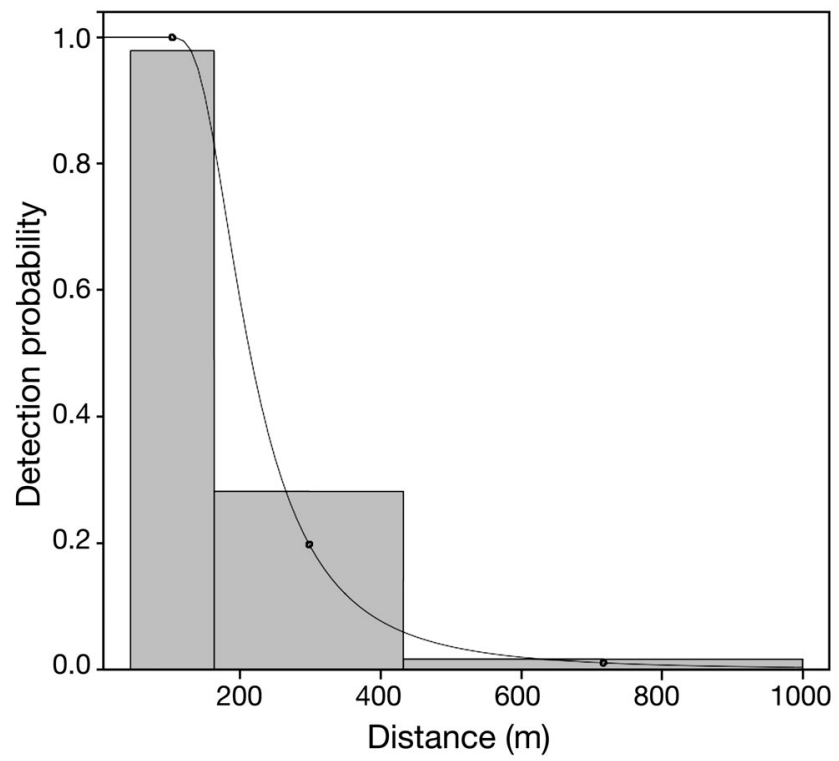

Fig. 2. Gavia immer. Distribution of perpendicular detection distances of all common loons observed on the water during aerial-based line transect surveys with the fitted (hazardrate) detection function (line) overlaid onto the scaled perpendicular distance distribution. Boxes: observation bins (see 'Aerial-based transect surveys')

\section{RESULTS}

There was a total of 951 common loon detections during the winters of 2010-2011 and 2011-2012. The majority of detections, $733(77 \%)$, were of solitary loons, with flocks of up to 30 loons accounting for the remainder of detections. The 24 survey transects were segregated into 495 segments of length $2270 \mathrm{~m}$, which produced a total of 2019 sample occasions (transects were surveyed multiple times, but sometimes one side could not be surveyed). Of these segments, $506(25 \%)$ contained loons, with a maximum estimate of 88.6 loons in a segment.

\section{Detection function}

A hazard-rate detection function with no covariates was selected (Fig. 2). Including flock size (as a continuous variable) and/or observer covariates (as a factor) in the scale parameter of the detection function changed the AIC by $<2$, so the detection function was modelled without covariates (see the Supplement). Half-normal models were significantly poorer models (i.e. $>19$ point difference in AIC terms to the next best hazard-rate model). Adjustment terms for the detection function were never selected by AIC. Further details of the detection function model selection

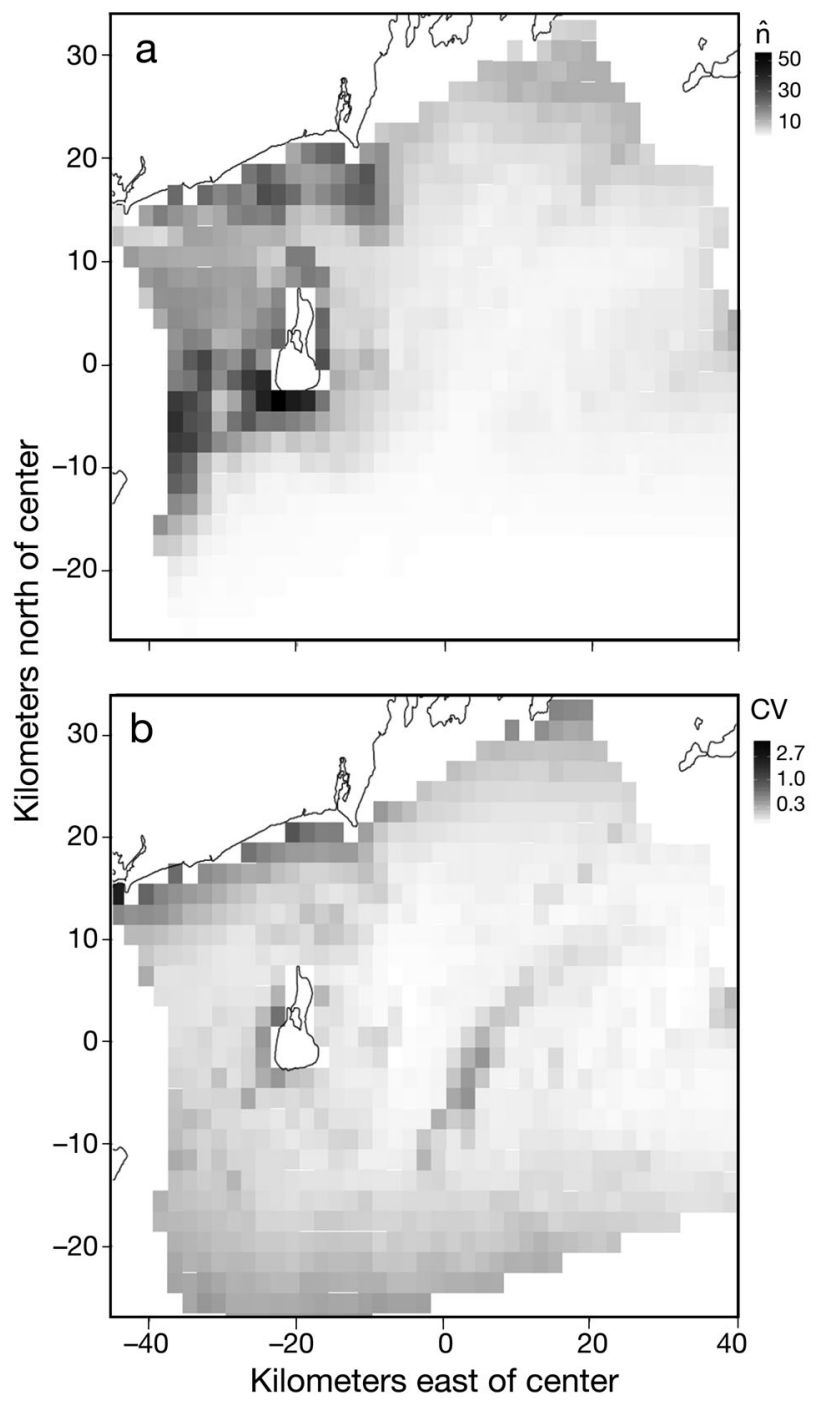

Fig. 3. Gavia immer. (a) Fitted density surface model of wintering common loons ( $\hat{\mathrm{n}}$ : ind. $\mathrm{km}^{-2}$ ) over the $3800 \mathrm{~km}^{2}$ Rhode Island Ocean Special Area Management Plan study area. Darker colors indicate higher densities of common loons in nearshore and in shallow waters. (b) Plot of the coefficient of variation $(\mathrm{CV})$ of common loon densities for the predicted surface showing the uncertainty in the predictions. Darker colors indicate higher model uncertainty. Further details in Fig. 1

procedure are given in the Supplement. Detection probability was relatively low ( $p \approx 0.2$; see Fig. 2 ) in observation Bin B (164-432 m) and close to zero in Bin C (433-1000 m).

\section{Density surface model}

The final DSM included smooth terms of mean chl a surface concentration from 2002-2012 (i.e. long-term geometric mean chl a), water depth and 

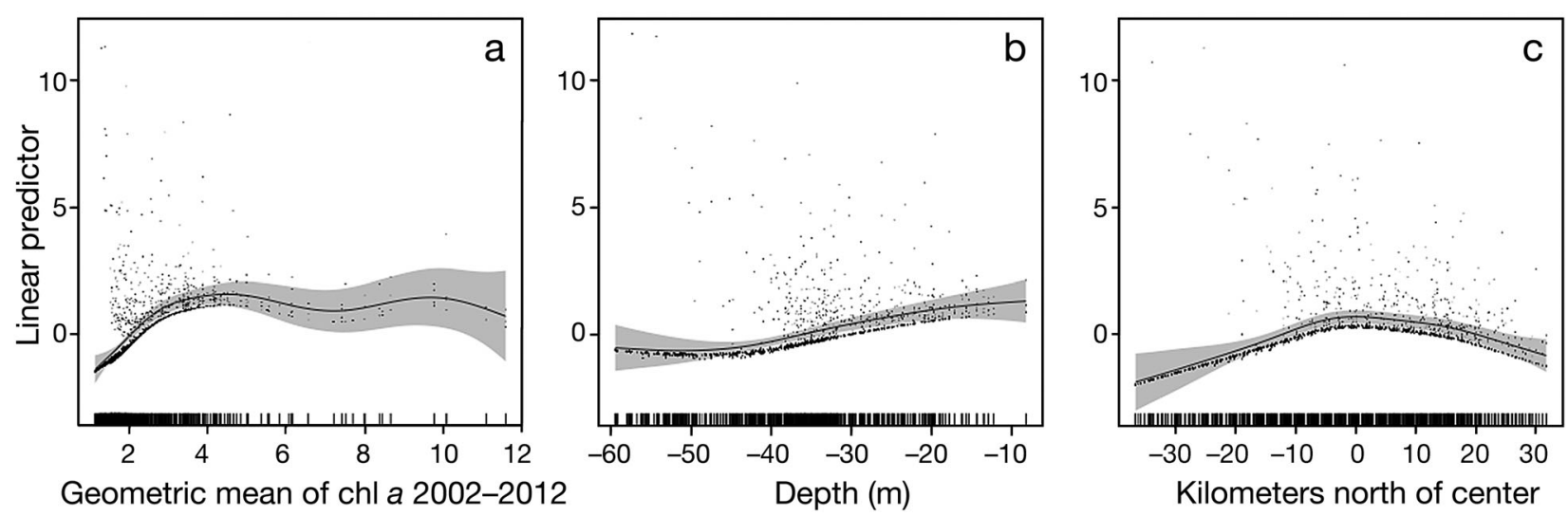

Fig. 4. Smooth functions for the factors included in the best model of wintering common loons Gavia immer: (a) geometric mean of chl a surface concentration from 2002-2012, (b) water depth, (c) latitude. Gray shading: approximate $95 \%$ confidence intervals

latitude $(y)$. The model estimated that the highest densities of common loons occurred in areas with water depths $<35 \mathrm{~m}$, high chl a concentrations $\left(>2 \mathrm{mg} \mathrm{m}^{-3}\right.$ ) and in the western portion of our study area surrounding Block Island (Fig. 3). These relationships can also be seen in the smooth plots of chl $a$ surface concentration (Fig. 4a) and latitude (Fig. 4c). The estimated abundance over the study area during winter was 5048 common loons $(\mathrm{CV}=0.12 ; 95 \% \mathrm{CI}=$ 3993-6379). A plot of the CVs for each prediction cell illustrated that there was higher uncertainty in abundance estimates nearer the coast (Fig. 3b).

\section{Model checking}

We performed a number of checks to ensure that our final model performed well and was insensitive to assumptions made in the modeling process (see the Supplement). First, the 4 best-performing detection functions (all hazard-rate, one without covariates, and 3 with the combinations of observer and group size) were used in the DSM and the results compared. In each case, the same environmental covariates were selected and the resulting smooth functions were almost identical. The selected model had both the highest adjusted- $\mathrm{R}^{2}(0.129)$ and highest percentage deviance explained $(37.7 \%)$. To ensure that there was a check for unmodelled spatial autocorrelation, correlations between segment residuals were calculated only within a given transect at various lags and displayed as a correlogram, which showed a small amount of residual correlation (Fig. 5). To check that the high correlation between the chl a metrics was not affecting the model fit, the model was refitted with the long-term chl a metric removed. This led to a model that selected neither of the other chl a measures. Aside from the negative binomial distribution, both Tweedie and quasiPoisson distributions were investigated as potential response distributions but neither yielded satisfactory residual plots. The availability bias correction was tested by varying the value from 0.5 up to 1 (no bias), which yielded predicted abundances that were within the confidence interval of the final model (bias correction $=0.7$ ) for values between 0.6 and 0.8 . Further details of sensitivity analyses (along with the code used to fit the models) are given in the Supplement.

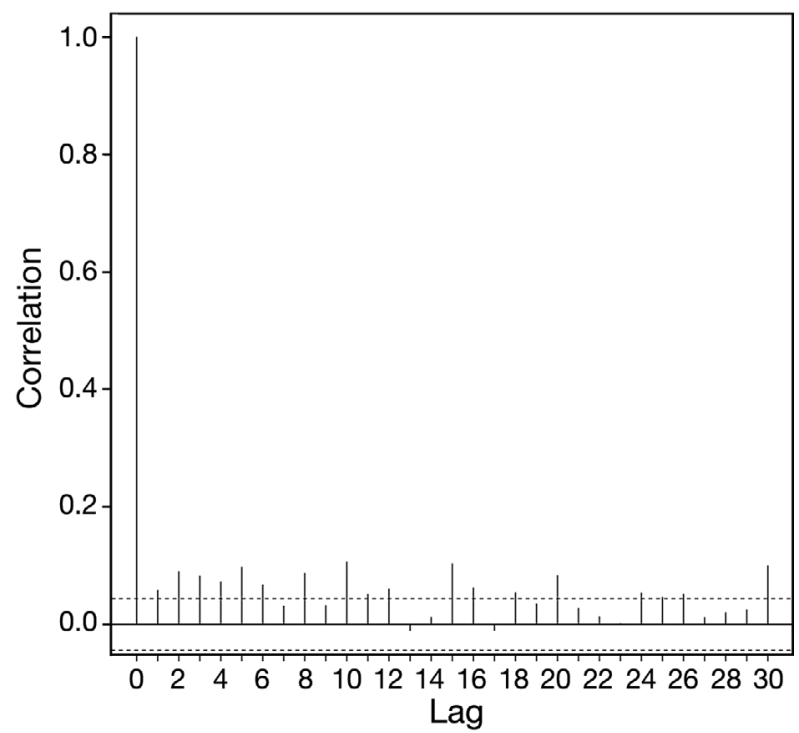

Fig. 5. Correlation of the residuals between segments of given lags. Lag 0 is the correlation between a segment and itself, Lag 1 between a segment and its immediate neighbours (i.e. segments that touch), Lag 2 between a segment and the segment one segment away, and so on. Correlations are only calculated within a given transect. The plot shows a small amount of unmodelled correlation in the residuals. Dotted lines: $95 \%$ confidence interval 


\section{DISCUSSION}

Common loons in our study area in southern New England were abundant during the winter months and found in the greatest densities in waters that were $<35 \mathrm{~m}$ and that had high long-term chl a surface concentrations $\left(>2 \mathrm{mg} \mathrm{m}^{-3}\right)$; these are presumably areas of consistently high primary productivity that support high densities of common loon prey. Our DSM accounted for imperfect detectability and provided a robust and flexible model-based approach for predicting the distribution and abundance of common loons, although predictive marine bird models could be improved with better data on (1) spatial distribution and abundance of marine bird prey species, and (2) longer-term systematic marine bird survey data. This type of spatially explicit model, which uses aerial line-transect data and incorporates relevant biotic and abiotic covariates, should be used by biologists, regulators and developers to inform their decisions about proper siting of offshore development, including OWEDs, and to provide better assessments of impacts of marine development on common loons and other marine birds.

\section{Environmental covariates predicting common loon distribution and abundance}

Our common loon DSM highlights key abiotic and biotic environmental drivers associated with the distribution and abundance of common loons that are mostly consistent with previous studies, although the model that we developed is the first to demonstrate that chl a surface concentration is a key biotic variable driving common loon distribution on their wintering grounds. Chl a surface concentration has been an important predictor of marine bird abundance in part because areas of high chl a surface concentrations tend to have high primary productivity, and thus higher forage biomass (e.g. fish, benthos) for top trophic predators such as common loons (Ribic et al. 1997, Yen et al. 2006, Gremillet et al. 2008, Suryan et al. 2012). Suryan et al. (2012) proposed that longer term measures of chl a surface concentration better predict marine bird distribution and abundance; our final best DSM for predicting the distribution and abundance of common loons contained the $10 \mathrm{yr}$ average chl a surface concentration but not the shorter-term measures. Although common loon abundance appeared to have a bimodal relationship with chl a surface concentration in our study area, this is likely just an artifact of low sample sizes in waters with concentrations $>6 \mathrm{mg} \mathrm{m}^{-3}$. Thus, our results for common loons support the hypothesis that longer-term measures of chl a surface concentration better predict marine bird distribution and abundance than shorter-term measures.

Suryan et al. (2012) also suggested that their metric of chl a anomalies (FCPI) may not be as useful for marine bird species with a more coastal distribution, such as common loons, where mean chl a values are on average higher in concentration. We found that FCPI was not selected as a covariate in our common loon model even when long-term chl a was removed as a candidate parameter. It is important to note that there were only 52 unique values for the FCPI in the observed data (compared to 281 for depth and 508 for long term chl a), so there may be insufficient information contained in the FCPI in comparison to the other covariates included in the model. Whether the differences in utility of FCPI are a matter of spatial scale (i.e. our study area is relatively small compared to that in Suryan et al. 2012) or related to its reduced importance in nearshore (our study) compared to more offshore (Suryan et al. 2012) environments is an open question for further research.

Common loons were most abundant in the waters of southern New England with high chl a concentrations $\left(>2 \mathrm{mg} \mathrm{m}^{-3}\right)$ as described above, but they were also more abundant in relatively shallower water depths (typically $<35 \mathrm{~m}$ ) and those waters southwest of Block Island, where loons may be attracted by the relatively low salinity from several major rivers including the Connecticut River and high tidal velocities, respectively (Mau et al. 2007, Codiga \& Ullman 2010). Higher densities of common loons in this area potentially indicate higher biomass of loon forage items including small demersal fish, crabs, lobsters and flounder (Evers 2007). The higher densities of common loons in relatively shallow waters is consistent with previous research by Kenow et al. (2009), who found that satellite-tagged common loons were most likely found in waters 3 to $20 \mathrm{~m}$ deep (see also Daub 1989). In contrast, Kenow et al. (2009) found that common loons were more common in areas with a relatively flat ocean floor, whereas we found that features of the ocean floor (i.e. bottom roughness and sediment grain size) were not included in our final model. Bottom roughness and sediment grain size may be less important than productivity (i.e. surface chl a concentration) in explaining the distribution and abundance of common loons in our study area because areas with high pro- 
ductivity that support high densities of diverse prey may be less directly associated with certain substrates in our area. Alternatively, areas with high productivity may allow loons to broaden their diet (e.g. benthic prey and demersal fish in the midwater column) and so be less reliant on a more restricted set of prey that are strongly associated with certain benthic habitat.

\section{Improving spatially explicit models for predicting marine bird abundance}

Our DSM accounted for imperfect detectability and provided a robust and flexible model-based approach for predicting the distribution and abundance of common loons, although refinements could further improve these predictive models. For example, our common loon DSM allowed us to identify key environmental covariates, yet the best model explained a modest $38 \%$ of the overall variance. Poor model fit and relatively low predictive power are not unusual for such marine bird predictive models (Oppel et al. 2012, Winiarski et al. 2014) in part because the distribution and abundance of marine birds is highly dynamic over space and time, and because such models of top predators in marine systems rarely have accurate spatially explicit information about their prey and instead must rely on other environmental factors that only indirectly relate to the distribution and abundance of prey. A better understanding of the environmental factors that determine the distribution and abundance of prey species would inevitably improve spatially explicit models of top predators such as common loons.

Most marine bird surveys are conducted within relatively brief time periods, which likely results in a relatively high number of false absences (see Oppel et al. 2012). A recently developed common loon DSM in our study area that used both shipbased and aerial strip transect data revealed how combining multiple data sets over longer timeframes and multiple spatial scales can lead to improved model performance (Winiarski et al. 2014). Our linetransect sampling was robust, contemporary, and controlled for imperfect observer detectability, but was relatively short in duration (during the winter months in 2 consecutive years). We need more longer-term systematic surveys of common loons on their wintering grounds so that we gain temporal resolution and thus improve the accuracy and precision of models that predict common loon distribution and abundance.

\section{Conservation implications for common loons in southern New England}

Our model predicted on average 5048 common loons (95\% CI = 3993-6379) wintering in our southern New England $3800 \mathrm{~km}^{2}$ study area, which was similar to estimates of common loon abundance estimated in the same study area in a previous winter using different survey protocols and a different predictive model (95\% CI = 4726-6489; Winiarski et al. 2014). These population estimates for common loons in our study area in southern New England confirm that this area contains key habitat for wintering common loons (Evers 2007).

Given the importance of southern New England for wintering common loons, and the prospects for OWED in this region (Department of Energy 2011), the predicted distribution and abundance of common loons from our density-surface models needs to be carefully considered when deciding where to develop these large-scale offshore energy-production facilities. Nearshore waters (Daub 1989, Kenow et al. 2009), which our model clearly shows are important for common loons, are attractive for OWED because they usually provide lower construction and operational costs than facilities further offshore (Snyder \& Kaiser 2009). We do not yet know the extent to which large-scale development will negatively impact this particular common loon population. Given the current conservation status of common loons in New England and our inadequate understanding of the population effects of displacement, we recommend that areas predicted to support high densities of common loons be excluded from OWED consideration. In our study area this includes the shallow waters southwest of Block Island that are known to be highly productive and important to a number of marine bird species, particularly wintering seaducks (Loring et al. 2014) and common loons (present study). Our DSM should also inform decisions about the location of new shipping routes that will be used during construction and maintenance of OWEDs because loons are sensitive to shipping and helicopter traffic (Schwemmer et al. 2011).

Continuing systematic surveys before and after OWED construction will further our understanding of the potential negative effects of OWED on common loons. Displacement from the developed area can be assessed with the model-based approach presented here (see also Petersen et al. 2011) which allows for incorporation of spatially explicit environmental covariates and accounts for spatial autocorrelation, both of which are known to be important for detect- 
ing changes in marine bird density in response to development (Pérez-Lapeña et al. 2010). Ultimately these spatially explicit abundance models can be used to inform decisions about siting of offshore development, including OWEDs, and to provide better assessments of impacts of marine development on common loons and other marine birds.

Acknowledgements. We thank the following people for their assistance with various aspects of the project. For help collecting survey data, we thank observers J. Veale and E. Jedrey. We also thank J. Chronic and D. McGowan of New England Specialized Aviation Services for piloting the Cessna Skymaster. This research was supported by grants from the State of Rhode Island for the Ocean Special Area Management Plan.

\section{LITERATURE CITED}

Alvo R, Hussell DJT, Berrill M (1988) The breeding success of common loons (Gavia immer) in relation to alkalinity and other lake characteristics in Ontario. Can J Zool 66: 746-752

Buckland ST, Anderson DR, Burnham KP, Laake JL, Borchers DL, Thomas L (2001) Introduction to distance sampling: estimating abundance of biological populations. Oxford University Press, London

Buckland ST, Anderson DR, Burnham KP, Laake JL, Borchers DL, Thomas L (2004) Advanced distance sampling. Oxford University Press, London

Burgess NM, Meyer MW (2008) Methylmercury exposure associated with reduced productivity in common loons. Ecotoxicology 17:83-91

Camphuysen CJ, Fox AD, Leopold M, Petersen IK (2004) Towards standardized seabirds at sea census techniques in connection with environmental impact assessments for offshore wind farms. UK COWRIE 1 Report. Royal Netherlands Institute for Sea Research, Texel

Codiga DL, Ullman DS (2010) Characterizing the physical oceanography of coastal waters off Rhode Island, Part 1: Literature review, available observations, and a representative model simulation. Rhode Island Ocean Special Area Management Plan, Narragansett, RI

Creaser EP, Perkins HC, Pierce F (1993) Common loons feeding on lobsters. Maine Nat 1:223-224

Daub BC (1989) Behavior of common loons in winter. J Field Ornithol 60:305-311

Department of Energy (2011) Offshore energy workshop. A joint workshop by the Energy Department's office of Energy Efficiency and Renewable Energy and the Department of the Interior's Bureau of Ocean Energy Management. Department of Energy, Washington, DC

Evers DC (2007) Status assessment and conservation plan for the common loon Gavia immer in North America. BRI Report 2007-20, US Fish and Wildlife Service, Hadley, MA

Evers DC, Kaplan JD, Meyer MW, Reaman PS and others (1998) A geographic trend in mercury exposure in common loon feathers and blood. Environ Toxicol Chem 17: 173-183

Ford TB, Gieg JA (1995) Winter behavior of the common loon. J Field Ornithol 66:22-29
Forsell DJ (1999) Mortality of migratory waterbirds in midAtlantic coastal anchored gillnets during March and April, 1999. US Fish Wildl Serv Tech Rep, Chesapeake Bay Office, Annapolis, MD

> Fox AD, Desholm M, Kahlert J, Christensen TK, Petersen IK (2006) Information needs to support environmental impact assessment of the effects of European marine offshore wind farms on birds. Ibis 148:129-144

> Furness RW, Wade HM, Masden EA (2013) Assessing vulnerability of marine bird populations to offshore wind farms. J Environ Manag 119:56-66

> Gremillet D, Lewis S, Drapeau L, van Der Lingen CD and others (2008) Spatial match-mismatch in the Benguela upwelling zone: should we expect chlorophyll and seasurface temperature to predict marine predator distributions? J Appl Ecol 45:610-621

Haney JC (1990) Winter habitat of common loons on the continental shelf of the southeastern United States. Wilson Bull 102:253-263

> Hedley SL, Buckland ST (2004) Spatial models for line transect sampling. J Agric Biol Environ Stat 9:181-199

Jung RE (1991) Effects of human activities and lake characteristics on the behavior and breeding success of common loons. Passeng Pigeon 53:207-218

> Kenow KP, Adams D, Schoch N, Evers DC and others (2009) Migration patterns and wintering range of common loons breeding in the northeastern United States. Waterbirds 32:234-247

Lafrance M, Shumchenia E, King J, Pockalny R, Oakley B, Pratt S, Boothroyd J (2010) Benthic habitat distribution and subsurface geology selected sites from the Rhode Island Ocean Special Area Management Plan study area. Rhode Island Ocean Special Area Management Plan, Narragansett, RI

> Langston RHW (2013) Birds and wind projects across the pond: a UK perspective. Wildl Soc Bull 37:5-18

Loring PH, Paton PWC, Osenkowski J, Gilliland SG, Savard JPL, McWilliams SR (2014) Habitat use of black scoters in southern New England and siting of offshore wind energy facilities. J Wildl Manag (in press)

> Louzao M, Bécares J, Rodríguez B, Hyrenbach KD, Ruiz A, Arcos JM (2009) Combining vessel-based surveys and tracking data to identify key marine areas for seabirds. Mar Ecol Prog Ser 391:183-197

> Mau JC, Wang DP, Ullman DS, Codiga DL (2007) Comparison of observed (HF radar, ADCP) and model barotropic tidal currents in the New York Bight and Block Island Sound. Estuar Coast Shelf Sci 72:129-137

McIntyre JW (1978) Wintering behavior of common loons. Auk 95:396-403

Miller DL (2012) Distance: a simple way to fit detection functions to distance sampling data and calculate abundance/density for biological populations. R package version 0.7.1. http://CRAN.R-project.org/package=Distance

Miller DL (2013) dsm: density surface modelling of distance sampling data. R package version 2.0.1. http://CRAN.Rproject.org/package=dsm (accessed 5 March 2013)

> Oppel S, Meirinho A, Ramírez I, Gardner B, O'Connell AF, Miller PI, Louzao M (2012) Comparison of five modelling techniques to predict the spatial distribution and abundance of seabirds. Biol Conserv 156:94-104

Pérez-Lapeña B, Wijnberg KM, Hulscher SJMH, Stein A (2010) Environmental impact assessment of offshore wind farms: a simulation based approach. J Appl Ecol 47: 1110-1118 
Petersen IK, Christensen TK, Kahlert J, Desholm M, Fox AD (2006) Final results of bird studies at the offshore wind farms at Nysted and Horns Rev, Denmark. National Research Institute Report, Ronde

Petersen IK, MacKenzie ML, Rexstad E, Wisz MS, Fox AD (2011) Comparing pre- and post-construction distributions of long-tailed ducks Clangula hyemalis in and around the Nysted offshore wind farm, Denmark: a quasi-designed experiment accounting for imperfect detection, local surface features and autocorrelation. CREEM Tech Rep no. 2011-1, University of St. Andrews, Edinburgh, http://research-repository.st-andrews.ac.uk/ handle/10023/2008

Powers, KD, Cherry J (1983) Loon migrations off the northeastern United States. Wilson Bull 95:125-132

R Development Core Team (2012) R: a language and environment for statistical computing. R Foundation for Statistical Computing, Vienna

Reid JM, Reid JA, Jenkins CJ, Hastings ME, Williams SJ, Poppe LJ (2005) usSEABED: Atlantic coast offshore surficial sediment data release. US Geological Survey Data Series 118, version 1.0, usSEABED, Reston, VA

Ribic CA, Davis R, Hess N, Peake D (1997) Distribution of seabirds in the northern Gulf of Mexico in relation to mesoscale features: initial observations. ICES J Mar Sci 54:545-551

Schwemmer P, Mendel B, Sonntag N, Dierschke V, Garthe S (2011) Effects of ship traffic on seabirds in offshore waters: implications for marine conservation and spatial planning. Ecol Appl 21:1851-1860

Sidor IF, Pokras MA, Major AR, Poppenga RH, Taylor KM, Miconi RM (2003) Mortality of common loons in New England, 1987 to 2000. J Wildl Dis 39:306-315

Snyder B, Kaiser MJ (2009) Ecological and economic costbenefit analysis of offshore wind energy. Renew Energy 34:1567-1578

Sperduto MB, Powers SP, Donlan M (2003) Scaling restoration to achieve enhancement of loon, seaduck, and other seabird populations. Mar Ecol Prog Ser 264:221-232

Suryan RM, Santora JA, Sydeman WJ (2012) New approach for using remotely sensed chlorophyll a to identify seabird hotspots. Mar Ecol Prog Ser 451:213-225

Thomas L, Buckland ST, Rexstad E, Laake JL and others (2010) Distance software: design and analysis of distance

Editorial responsibility: Yves Cherel,

Villiers-en-Bois, France sampling surveys for estimating population size. J Appl Ecol 47:5-14

Thompson SA, Price JJ (2006) Water clarity and diving behavior in wintering common loons. Waterbirds 29: 169-175

Titus JR, VanDruff LW (1981) Response of the common loon to recreational pressure in the Boundary Waters Canoe Area, northeastern Minnesota. Wildl Monogr 79: $5-59$

> Tremblay Y, Bertrand S, Henry RW, Kappes MA, Costa DP, Shaffer SA (2009) Analytical approaches to investigating seabird-environment interactions: a review. Mar Ecol Prog Ser 391:153-163

Watson H, Hiddink JG, Hobbs MJ, Brereton TM, Tetley MJ (2013) The utility of relative environmental suitability (RES) modelling for predicting distributions of seabirds in the North Atlantic. Mar Ecol Prog Ser 485:259-283

- Williams R, Hedley SL, Branch TA, Bravington MV, Zerbini AN, Findlay KP (2011) Chilean blue whales as a case study to illustrate methods to estimate abundance and evaluate conservation status of rare species. Conserv Biol 25:526-535

Winiarski KJ, Trocki CL, Paton PWC, McWilliams SR (2011) Spatial distribution, abundance, and flight ecology of birds in nearshore and offshore waters of Rhode Island: January 2009 to August 2010. Rhode Island Ocean Special Area Management Plan, Narragansett, RI

Winiarski KJ, Burt LM, Rexstad EA, Miller DL, Trocki CL, Paton PWC, McWilliams SR (2014) Integrating aerial and ship surveys of marine birds into a combined density surface model: a case study of wintering common loons. Condor (in press)

- Wood SN (2003) Thin plate regression splines. J R Stat Soc B 65:95-114

Wood SN (2006) Generalized additive models: an introduction with R. Chapman \& Hall/ CRC, Boca Raton, FL

> Wood SN (2011) Fast stable restricted maximum likelihood and marginal likelihood estimation of semiparametric generalized linear models. J R Stat Soc B 73:3-36

> Yen PPW, Sydeman WJ, Bograd SJ, Hyrenbach KD (2006) Spring-time distributions of migratory marine birds in the southern California Current: oceanic eddy associations and coastal habitat hotspots over 17 years. DeepSea Res II 53:399-418

Submitted: March 8, 2013; Accepted: July 25, 2013

Proofs received from author(s): October 25, 2013 